Volume 16 Issue 3 Year: 2019

\title{
Evaluate the existing political oversight role of Turkish parliament over the public finance and in this context analyzed the new Turkish Presidential Government System ${ }^{1}$
}

\author{
Mustafa Biçer
}

\begin{abstract}
Turkey changed its 1982 Constitution and adopted a presidential form of government in 2017. This constitutional amendment changed the approval of the budget radically. Along with that, debates may arise in terms of political responsibility for not approved the budget by the Parliament, how the budget will accepted when the president and majority of the Parliament are from different party, and there is not any mechanism being in classical presidential system as public account committee to enhance parliamentary supervision over the executive branch.

In this study,

- we deliberate the concept of political power in representative democracy in terms of public decision-making and resource allocation process and then we analyze the existing political oversight role of Turkish Parliament over the public finance on the basis of democratic legitimacy of public decision-making process and political accountability.

- we focus on oversight role of Turkish Parliament over the public finance at the point of using "power of purse after the Constitutional Amendment adopted on April 16, 2017. Within the context of this analysis, the new constitutional structure of Parliament's budget approval and audit process in Turkish Parliament was evaluated.
\end{abstract}

Keywords: Turkish presidential government system; political representation; political accountability; governmental systems; 2017 constitutional amendment.

\footnotetext{
${ }^{1}$ This article was presented as a paper at the International Conference on Science and Education (IConSE), Antalya / Turkey, October 26-29, 2018.

2 Ph.D., Legislative Experts, Grand National Assembly of Turkey, Laws and Resolution Department, mustafabicer69@yahoo.com.tr
} 
Biçer N. (2019). Evaluate the existing political oversight role of Turkish parliament over the public finance and in this context analyzed the new Turkish Presidential Government System. Journal of Human Sciences, 16(3), 746-761. doi:10.14687/jhs.v16i3.5666

\section{Introduction}

"Magna Carta Libertatum" (1215) which is attempt to limit the financial power of absolute authority, is considered beginning of the parliament that is composed of representatives of the citizens. This historical and social development has been conceptualized in the political literary literature as "power of the purse". The "power of purse," which is the result of the gradual gains in the institutionalization of representative democracy over a period of nearly 800 years, has become an indispensable factor of representative democracy today. In the historical process the "power of purse," have enabled legislative body to get power over taxation and empower on prioritization of public expenditures. This legislative accepting the budget and monitoring budget outcomes have led to the development of budget as a means of political control over the executive. In modern democracies, this checks and balances system between the executive and the legislative bodies is structured in the constitutions.

The tendency of constitutionalism in Europe has strengthened with feudalism. In the Middle Ages Europe, especially in the southern European countries, the idea of the inalienability of human rights in natural law, which is effective in Roman law, has been contrary to constitutionality, but it has been a strengthening element of the constitutionalism movement (Lane; 1996:22). Cicero, one of the leading representatives of Roman law, mentioned a model of the mixed government (moderatus et permixtus) in his Republic. This government model of Ciceron was revealed in the constitutionalism movement in the 16th and 17th centuries (Lane; 1996: 24). Towards the end of the 18th century, power of the purse was institutionalized in America and France and in the 19th century by the constitutionalism movement spreading to other European states. Today, power of the purse has been one of the basic cornerstone of representative democracy.

On the other hand, in 2017, Turkey changed its 1982 Constitution and adopted a presidential form of government. These changes will be implemented after the first scheduled presidential and assembly elections that will take place on the same day in 2019, unless early elections are called. This constitutional amendment changed the duties of the executive body; methods of elections; the regulations concerning the judiciary; the investigation and trial procedures for the president, ministers, and vice presidents; the president's power of executive order; and the approval of the budget.

The new constitutional structure of the government system does not fundamentally make any significant amendment, except in the form of submission of budget proposals and changes in the member structure of the budget committee and provisional budget implementation. Along with that, debates may arise in terms of political responsibility for not approved the budget by the Parliament, how the budget will accepted when the president and majority of the Parliament are from different party, and there is not any mechanism being in classical presidential system as public account committee to enhance parliamentary supervision over the executive branch.

The above conceptual framework in this study,

- we deliberate the concept of political power in representative democracy in terms of public decision-making and resource allocation process and then we analyze the existing political oversight role of Turkish Parliament over the public finance on the basis of democratic legitimacy of public decision-making process and political accountability.

- we focus on oversight role of Turkish Parliament over the public finance at the point of using "power of purse after the Constitutional Amendment adopted on April 16, 2017. Within the context of this analysis, the new constitutional structure of Parliament's budget approval and audit process in Turkish Parliament was evaluated. 
Biçer N. (2019). Evaluate the existing political oversight role of Turkish parliament over the public finance and in this context analyzed the new Turkish Presidential Government System. Journal of Human Sciences, 16(3), 746-761. doi:10.14687/jhs.v16i3.5666

\section{Oversight of Public Resources in Representative Democracy}

As a representative body, parliaments emerged as the result of political and social developments in England after the XII century, and over time, they gained their present position in modern democracy. In the emergence of the first examples of parliaments, it was effective to prevent the King from imposing taxes on the basis of his sole discretion. In this context, parliament is entitled to levy taxes with the Magna Carta Libertatum of 1215 in the United Kingdom. Later, with the Bill of Rights, which was adopted in 1688, taxation was entirely among the powers of parliament. In the following stage, the aim of the parliament was to oversight the expenditure of taxes. Thus, the concept of "power of the purse" has emerged and authority to determine public expenditures and accordingly public services has been recognized as an authority belonging to the representative body/parliament in the representative democracy. Nowadays, the concept of collecting taxes and spending of these taxes by parliamentary decision constitutes the basic institutional structure of representative democracy.

In the transition to a model of democracy based on political representation, the historical and sociological development towards the restriction and accountability of the political power/government that conceptualized as power of the purse has constituted an important cornerstone. In this process of transformation, with the elimination of absolute power, parliaments have begun to share their authority on public finance along with democratically elected executive bodies in representative democracies. Parliament entitled to the determination of public services; authorizing taxes and public expenditure have led to being developed the budget as the most important means of parliamentary oversight on the executive (Yllmaz and Biçer, 2010, p.202). The modern budgetary process is a product of this long and vexed development, involving governments as the key decision-makers on most issues but also parliaments as keepers of the ultimate seal of approval.

\subsection{Powers of the Purse in Representative Democracy}

Representative democracy, a practice of democracy, has evolved as a system of institutions in context of political events arising from the transformations / revolutions in England, America and France. Today, the content of the theory of representative democracy, which transcends its geographical location and transformed into a universal value, reflects the historical experience of Western Europe. The focus of this historical experience is power of the purse, political representation and parliament (Biçer, 2017, p.9).

The history of representation and its practice in political life dates back to the Roman Empire. In Rome, there were the Senate, where the Aristocrats were represented, but also four assemblies, each called comitia ("assembly") or concilium ("council"); the Comitia Curiata, the Comitia Centuriata, Concilium Plebis and the Comitia Tributa (Şenel;2017:203-205). However, the 1215 Magna Carta Libertatum is the most important cornerstone of these historical developments. Magna Carta, which is an attempt to limit the fiscal authority of the absolute power, is accepted as the starting date of the parliament consist of the representatives of the people. After this important turning point, intellectual developments towards limiting the absolute power of political authority in western political thought gained speed in the age of enlightenment period.

In the age of enlightenment period, the concepts of "sovereignty" and "social contract" developed by Thomas Hobbes (1588-1679) were reassessment and theorized by John Locke, (16321704) and Jean-Jacques Rousseau (1712-1778) in different approach. Another important concept of representative democracy was separation of powers theorized by Montesquieu (1689-1755) in this period. Today, the separation of powers and the theory of social contract are the cornerstones of representative democracy (Şenel; 2017: 364-397). The 1776 American Independent War and the constitutional arrangements prepared after the 1789 French Revolution structured the 
Biçer N. (2019). Evaluate the existing political oversight role of Turkish parliament over the public finance and in this context analyzed the new Turkish Presidential Government System. Journal of Human Sciences, 16(3), 746-761. doi:10.14687/ihs.v16i3.5666

institutionalization of the separation of powers with the power of the purse within the framework of the budget. In the 19th and 20th centuries, with the development and adoption of a set of budget principles, the power of the purse has become an indispensable element of the representative body.

In Europe the power of the purse, institutionalized in line with the principles and philosophy of Magna Carta with being the first written document to limit the discretionary power of absolute governments, has developed in line with the limitation of the financial powers of the government in the sphere of taxation and spending. With the Magna Carta, the separation of powers in financial matters has been actually implemented as a result of the limitation of the king's sole authority on taxation (Hetzel, 1997, p.47.). After Magna Carta, other constitutional documents limiting the king's taxation power in England, 1628 Petition of Rights and 1689 Bill of Rights (Çağan, 1980, p.131). These historical developments have ensured the institutionalization of the separation of powers, which means the fragmentation and limitation of government's absolute power (.Biçer, 2017, p.12). The theory of separation of powers was developed in order to protect freedoms against absolutist regimes, especially in the XVIII century. The main philosophy of the separation of powers is to divide state sovereignty into executive, legislative and judicial functions (Çağan, 1980, p. 133).

After the US Constitution, the principle of separation of powers, which determines the constitutional and institutional boundaries of political power, has become a primary issue in terms of the functioning of representative democracy by gaining its present function and importance. The principle of the separation of powers, which is designed by the Constitution, has now become the most fundamental constitutional institution in representative liberal democracies. Today, representative democracy internalizing the principles of limited political power and popular sovereignty, is used in line with the concept of democratic state (Saybaşll, 1992, p.8).

Representative democracy, developing as capitalist democracy, is a political-economic system (Sartori, 1996). In this political-economic system, there are four main mechanisms that balance public financial management, increase effectiveness and improve efficiency. These are public borrowing mechanism, taxation system, functions of central bank and parliament. Within this balance system, parliaments have the status of the sole legitimate representative body, in which all decisions and practices of public borrowing, taxation and central banks are discussed, at least the design of which is discussed, and the implementation of these decisions are audited. For this reason, in the concept of classical sovereignty, parliament is considered as the basic and top-level decision-making body of economic policy in representative democracy, since it has the authority to determine the legal framework and preconditions of the activities of the decision-making bodies of the macroeconomics policy (Santiso, 2005, p.4). In this classical conception, without the permission of parliament, the government not having the authority to collect revenue and spend public resources is an indicator of the parliament's absolute power in the field of public finance. In this sense, as the top decision-maker on public resources, the parliament decides on the financial movement area that the executive body will have and the way in which the necessary public resource will be provided. In other words, parliament decides on what amount and how resources will be transferred from the private economy through the budget (Biçer, 2017, p.147).

\subsection{Political Accountability}

In representative democracy, open, free and fair elections that constitute the essence of the democratic system offer the most appropriate political platform to maximize the interests of the groups in the society. The struggle of the interest groups mainly takes place in this institutionalized political platform. The political parties representing these interest groups compete for political power, and the purpose of this competition is to take power and to realize the public decisions and group interests in the maximum possible extent. The representative democratic system is a mechanism that regulates the content and rules of this competition (Şaylan, 1998, p. 88). In the economic sense, 
Biçer N. (2019). Evaluate the existing political oversight role of Turkish parliament over the public finance and in this context analyzed the new Turkish Presidential Government System. Journal of Human Sciences, 16(3), 746-761. doi:10.14687/jhs.v16i3.5666

because of the fact that every decision taken by the political power has a social cost, the electoral competition in the representative democracy takes place mainly in the economic / financial field (Fabrizio and Ashoka, 2006, p. 7). In this sense, representative democracy requires a dynamic political struggle position with a clear conflict of interests in a properly functioning democratic process (Mouffe, 2008, p. 20).

In representative democracy, another function of the elections is to provide voters hold politicians with being accountable for the policies they have implemented in the past. In representative democracy, elections have a major democratic function that enables governments to make political accountability and allow citizens to choose between alternative programs and politics. The most important problem in representative democracy is the balance between the broadest representation and financial accountability, and in this sense, democratic elections play a key role in establishing a balance between representation and accountability (Fabrizio and Ashoka, 2006, p.7).

In representative democracies, the fact that the political power has the right to govern and is responsible against to the citizens, as a result of the political preference of the voters, that is, their consent, is considered as democratic accountability. Democratic accountability obliges those who take decisions relating to citizens by using state power to be accountable to those having consent. In this sense, consent and accountability constitute the two main axes of the democratic political system (Şaylan, 2008, p.192). Since democracy is a system of delegation, the establishment of political accountability is the most basic institutional existence for the representative body / parliament. Today, political accountability, which conceptualizes as democratic accountability, is dealt with within the principal-agent theory (Harfst and Schnapp, 2003, p.3).

In the representative democracy, the transfer of authority from the citizen to the politician takes place through elections, which are a basic democratic institution of representative democracy (Wolfgang, et al, 2003, p. 19). In this process, voters empower their representatives (politicians) to make public policy within the constitutional and legal boundaries. As a result of this empowerment, naturally, representatives must be accountable to the citizens as they use the authority that belongs to the citizens. This responsibility presents itself as political control in the form of a responsiveness and accountability relationship between the principals and agents (Şaylan; 2008, p.203). This political control function constitutes the focal point of political accountability (Erdoğan, 2010, p. 335). Political accountability is largely experienced in the budget approval and audit process. This budget process serves as an indispensable political control function in all democratic countries and provides a mechanism through which the accountability of the executive body is ensured.

The allocation of resources to public policy and services undertaken by the state in representative democracy is determined not in the market process, but in a political process, that is, in the budget process (Musgrave and Musgrave, 1989, p.87). Therefore, the political struggle in the representative democracy focuses on the budget, which is the process of distributing the costs and the amount of resources to be allocated to public services undertaken by the state.

\subsection{Function and Importance of Budget Process in Representative Democracy}

With the present function and importance, budget system has followed a progress parallel to the development of Western democracies since the 18th century. The budget system has evolved in parallel to the formation of capitalist state in representative democracy and developed as a platform in which unequal power relations are seen as being excluded or involved in the process of different social groups from the decision-making process. Within this platform, the dynamics of the economic and political structure are decisive in order to determine and direct the volume of public expenditures through mutual interaction. That is, the volume and composition of public expenditures and the sharing of tax burden are determined not by market laws but by social and economic struggles between classes and groups. (O'connor, 1973, p. 2) 
Biçer N. (2019). Evaluate the existing political oversight role of Turkish parliament over the public finance and in this context analyzed the new Turkish Presidential Government System. Journal of Human Sciences, 16(3), 746-761. doi:10.14687/jhs.v16i3.5666

In representative democracy, Parliaments are differentiated in two main points in terms of budget approval and audit process. The first is the authority and capacity of legislative bodies to change the budget; the second is how the legislative bodies have structured their approval and audit process of the budget. This distinction is structured according to the government system of the countries and the situation and authority of the parliament is determined depending on whether the system of government is presidential or parliamentary system. Parliaments' authority on the budget in different government systems are formally contained in the constitution and laws, but this legal situation does not, in practice, demonstrate the actual capacity of parliaments to exercise their constitutional powers.

As the highest decision-making authority in the distribution of public resources the parliament, in the framework of the authority laid down in the constitution, decides on the extent to which the executive branch will have the necessary financial resources and the way in which the necessary public resource is to be procured. In other words, the parliaments decide what amount and how much resources to be transferred from the private economy through the budget. However, in practice, despite this legitimate power, the parliaments in representative democracies transferred their actual use of power and authority to the government and bureaucracy because of the increase in state activities in the 20th century and due to the need for increased technical expertise (Santiso,2005, p. 4). In addition, due to political reasons such as the establishment of the government and political party structure in the parliamentary system of government and the veto power of the executive body in the presidential system of government, in terms of the determination of fiscal policy there is a difference between authorities of parliament defined in constitution and the actual authorities of the parliaments (Inter-Parliamentary Union, 2004, p.45). This difference in practice directly affects the quality of the government and regime.

Parliamentary oversight is the need for build confidence and legitimacy in the representative democracy. In addition, Parliamentary oversight is the need to enhance policy learning and policy innovation. Examining the implementation of established policies and learning from experience is important to improve the quality of future decisions. This makes oversight procedures essential elements in any form of representative democracy.

In general, the issue of political accountability is important in terms of fiscal policy and budget policy in particular. The formation of fiscal policy depending on the political decision-making process is one of the main factors that determine the failure of budget policies, especially in developing countries (Atiyas ve Sayin, 1997, p. 3). In this context, the well-functioning of the government system provides the success of the budget policies also.

The setting of the budget is widely thought to be every democratic parliament's single most important power and responsibility. How this power is best understood and measured is subject to a lively debate. Important variables that tend to be highlighted include Parliament's capacity to influence both the overall envelope of the state budget and sectoral allocations; amending powers in relation to the budget bill; the extent, quality and accessibility of the information that accompanies the budget bill; the time and resources that committees and plenary have at their disposal in considering and debating the budget; and the discretion accorded to the executive in implementing the budget and, if considered necessary, deviate from the provisions of the budget law.

There are different stages in the budgetary process: requests, central priority-setting, legislation, execution, auditing and scrutiny. The formal parliamentary involvement is normally concentrated to two of these stages, the legislative phase including examination of the budget proposal and the retrospective scrutiny of the public accounts. The first stage is to establish the budget. It is a forwardlooking activity in which discussions on the priorities for the next budget will take place. Which policy areas shall have what amount of money? This work is in general carried out in Budget Committees 
Biçer N. (2019). Evaluate the existing political oversight role of Turkish parliament over the public finance and in this context analyzed the new Turkish Presidential Government System. Journal of Human Sciences, 16(3), 746-761. doi:10.14687/jhs.v16i3.5666

or Finance Committees. The second stage is a retrospective activity during which parliaments exercise control over the implementation of the budget. Parliaments will check whether the last budget was spent wisely, for its intended purposes and in accordance with all regulations. This activity is normally carried out by budgetary control committees or public account committees with a different name but similar functions.

\section{Constitutional Structure of Parliamentary Oversight of Public Resources after the Last Constitutional Amendment in Turkey}

In Turkey, parliamentary government system was implemented from the proclamation of the Republic in 1923, until the Presidency and the Parliamentary Election in June 24, 2018. The parliamentary system of government has been transformed into a government system called "the Executive Presidency system", where the all authority of the executive is concentrated in the elected President.

After June 24, 2018, Turkey has passed into from the executive's power concentrated in the Council of Ministers deriving its legitimacy from parliament to a presidential government model deriving its legitimacy from the public directly. Hereafter, the Executive Presidency system is a government system where executive and legislative are elected separately by public vote. That is, the executive branch will take its democratic legitimacy from the nation itself, not from the legislature. With this constitutional amendment, members of the government as ministers appointed by the president doesn't require Parliament's approval and anymore ministers is not accountable to the Parliament.

Under the Constitution of 1982, the legislative power is vested in the Grand National Assembly of Turkey (GNAT). Article 7 regulates this constitutional rule as follows: Article 7 is specified as "Legislative power is vested in the Grand National Assembly of Turkey (GNAT) on behalf of Turkish Nation. This power shall not be delegated." In addition to that, amended article 8 of the Constitution specify using the executive power as follows, "Executive power and function shall be exercised and carried out by the President of the Republic and the Council of Ministers in conformity with the Constitution and laws." It is understood that the legislative power will continue to be carried out by GNAT and all executive power previously hold by the prime minister and ministers is transferred to the president. Anymore the president and the ministries have no authority to draft a bill. The authority given to the president regarding the proposal of bill is to only submit the budget proposal to the GNAT.

According to amended article 104 of the Constitution, the head of state/president may issue presidential decrees on matters of executive power. In the event of conflict between presidential decrees and existing laws, the latter would prevail. The president may issue by-laws to ensure the implementation of laws, providing that they are not contrary to these laws and regulations. Although the scope of this right is narrow and laws will continue to take precedence over decrees, this will give the president a limited legislative power. There was a special law making mechanism by enabling law to issue decrees having the force of law on certain subjects within the limits prescribed in the Constitution in the previous government system as called decrees having the forces of law. The Assembly could authorize the Council of Ministers to issue decrees having the force of law. However, the GNAT required defining the purpose, scope, principles, and operative period of the decree having the force of law according to previous rules of the Constitution.

Another important amendment is about constitutional structure of legislative budget process. Naturally, the constitutional structure of legislative budget process were adjusted according to the presidential system. In this new legislative budget system, the president will prepare a proposal for the budget and submit it to Parliament and this budget proposal is discussed and approved only by 
Biçer N. (2019). Evaluate the existing political oversight role of Turkish parliament over the public finance and in this context analyzed the new Turkish Presidential Government System. Journal of Human Sciences, 16(3), 746-761. doi:10.14687/jhs.v16i3.5666

Parliament. Now, first, it will be briefly explained previous constitutional structure of legislative budget process, and then this budget process will be evaluated in the executive presidency system.

\subsection{Previous Legislative Budget Process}

As are in countries with a democratic system based on representation, democratic scrutiny/oversight of public finances in Turkey are carried out by Parliament/GNAT in the framework drawn in the Constitution. Until the transition to the Executive Presidency system, GNTA carried out this oversight in two ways, namely, oral and written questions to government, parliamentary inquiry, general debate, introducing motions of censure, calling for votes of nonconfidence and parliamentary investigations, as well as the budget approval and audit process. In the Executive Presidency system, GNTA lost some oversight functions such as motions of censure, calling for votes of non-confidence and oral questions to government which are peculiar to parliamentary government system. Anymore, GNAT will exercise its powers of acquiring information and oversight functions by means of parliamentary inquiry, general debate, parliamentary investigations and written questions with the budget approval and audit process.

In general term, Parliament's powers over the budget are principally set down in the Constitution and in the Public Financial Management and Control Law in Turkey. The institutional structure of the legislative approval and audit of the budget is composed GNAT and the Turkish Court of Accounts (TCA), The organizational structure in the GNAT, the Plan and the Budget Committee, where the budget and final account draft laws were first discussed and audited, and the General Assembly of the GNAT, where these draft laws were finally discussed and enacted. The second pillar of the institutional structure is the Court of Accounts, which carries out the indirect audit on behalf of the GNAT and reports the results of this audit to the Parliament according to relating articles of the Constitution, the Public Financial Management and Control Law of 5018, Law No. 6085 On Turkish Court Of Accounts. Parliamentary oversight of public expenditures is carried out by the TCA, which presents its audit (Statement of Conformity) to the parliament following the end of the fiscal year.

Previous constitutional structure of legislative budget process was defined by between 161 and 164 articles of the Constitution. These four articles (161,162,163 and 164) dealt in general with the broadest principles of public management and control system: specify the deadlines for presenting the draft budget bill and final accounts to parliament, and regulate parliamentary debates on the budget. In this constitutional framework, there was one permanent parliamentary committee on plan, budget and final account: The Plan and Budget Committee in GNAT. According to amended article 162 of the Constitution the legislative stage of the budget process could be divided into two steps: the Plan and Budget Committee and plenary session of GNAT (CRT, 2018).

In this constitutional framework, legislative budget process was regulated as follows:

- According to Article 162 of the Constitution stated that the executive would submit the central government budget draft law (budget bill) to the Turkish Grand National Assembly (the Parliament) 75 days prior to the beginning of the fiscal year.

- The Plan and Budget Committee of the Parliament first considered the draft budget. The Committee had to adopt the budget bill as amended within 55 days, which subsequently was considered by the Parliament in plenary session within 20 days. In other words, 55 days out of 75 , which were allocated to the budgetary debates in Parliament, was reserved only for the Plan and Budget Committee. In the Committee stage, there were not any limitations in the Constitution or in the laws as to be proposed amendments by the Members of the Committee for increasing revenues or decreasing revenues; increasing expenditures or decreasing expenditures or making transfers among appropriations. For this reason, depth and more technical debate could take place in this Committee stage, although the stage of plenary session was more political and ceremonial. Members 
Biçer N. (2019). Evaluate the existing political oversight role of Turkish parliament over the public finance and in this context analyzed the new Turkish Presidential Government System. Journal of Human Sciences, 16(3), 746-761. doi:10.14687/jhs.v16i3.5666

of Parliament only could express their opinions on public bodies and over all policies of government during this debates.

- The budget bill was then approved by the Parliament and promulgated by the President of the Republic and became effective as of 1 st of January.

The Plan and Budget Committee is one of the Parliamentary committees. It comprised 40 members, of who 25 represent the governing party or parties and 15 the oppositions. On the other hand, if there was even a minority government in power, 25 members of the Plan and Budget Committee were from the ruling party. With this regulation, the government has been granted a privilege for the Council of Ministers to negotiate and approve the budget, which has gained the character of a vote of confidence. Thus, in the Constitution, plans and budgets to be finalized by a specialized committee in which the government had a majority, and the budgetary balances adopted here were to prevent the breakdown in the Plenary Session. Therefore, according to the constitution, members of the GNAT were not able to raise expenses or reduce incomes during the discussion of the draft budget in the Plenary Session. The Plan and Budget Committee would serve as the main platform on scrutinize proposed government budget prior to parliamentary approval. Departmental committees formally did not participate in the budget negotiations. That is to say, there was not a rule to formulate the involvement of the departmental committees to the legislative budget process either the Parliament's rules of procedure or laws.

When we look at the effectiveness of the budget at the committee stage in the previous system, it is seen that the Committee is not effective in determining the budget appropriations. In theory, members of the Plan and Budget Committee were allowed to make changes over the composition of budget appropriations without any legal limitation according to the Constitution. However, because of the party's disciplined, in realty, such power was considerably weaker. Due to the fact that members of the governing parties had the majority in the Plan and Budget Committee, the discussions and supervision of the committee was weakened in terms of parliamentary supervision.

From the perspective of the representative theory of democracy, the acceptance or rejection of the budget draft law has a political issue in the sense of a vote of confidence or non-confidence. In the parliamentary government system, the government's approval of the budget due to the majority of the Parliament, the government's vote of confidence, disapproval or refusal is a vote of non-confidence.

Constitution structure of final accounts was defined in the amended article 164. According to the amended article 164 of the Constitution final accounts bill would be submitted to the Parliament by the Council of Ministers within seven months of the end of the relevant fiscal year, unless law prescribed a shorter period. The final accounts bill was considered by Parliament together with the central government budget bill. Both the previous year's accounts and the following year's appropriations were approved by Parliament at the same time.

Under the actual Constitution and the Law on the Turkish Court of Accounts (TCA), the TCA audits on behalf of the GNAT the revenues, expenditure and properties of public administrations. In this auditing, reliability and accuracy are to be examined, as well as economy, efficiency and effectiveness. The main document submitted by the TCA to Parliament is the annual Statement of General Conformity. This document is complemented by various other reports as provided for in the Law on the TCA and the Public Financial Management and Control Law. Increasingly, this also includes 'performance audit reports', which examine the performance of different parts of public administration in terms of their efficiency, effectiveness and economy. The task of discussing the reports and approving the Consolidated Final Accounts falls to the Plan and Budget Committee. There is not a special committee on approving final accounts in the present legislative budget process. 
Biçer N. (2019). Evaluate the existing political oversight role of Turkish parliament over the public finance and in this context analyzed the new Turkish Presidential Government System. Journal of Human Sciences, 16(3), 746-761. doi:10.14687/jhs.v16i3.5666

In sum, normatively, the GNAT seems to have a wide range of means to scrutinize the government in the process of budget preparation, approval, execution and audit in the previous constitutional legislative budget structure. However, the broad formal powers given to the Parliament on the budget is not enough to understand quality and effectiveness of parliamentary scrutiny over public financial management system. Considering the effectiveness of parliamentary oversight until 24 June 2018; Parliamentary / democratic oversight of public finances was ineffective due to the constraints caused by the parliamentary government system and the lack of administrative capacity in the GNAT. This has raised the issue of a continuous critiques on the audit capacity of the legislature, ex ante (approval phase) and ex post (after execution) of the budget oversight. Along with that, it also points to the problem of an effective check and balance between legislative and executive. In this context, there are many scientific articles, symposiums and research studies published in the past years. Some of those are (OECD/SIGMA, 2010), (TBMM, 2008) and (Yildiran, at all, 2010).

\subsection{Legislative Budget Process in the New Executive Presidency System}

With the Law No. 6771 Amending the Constitution, the provision of "Preparation and Implementation of the Budget", "Debate on the Budget", "Principles Governing Budgetary Amendments" and "Final Account" regulated by Articles 161, 162, 163 and 164 of the Constitution are collected and amended in Article 161 under the "Budget and Final Account" heading.

The process of new constitutional approval of the budget and audit of final account in amended article 161 is summarized below:

a) The budget draft law was proposed by the President as a budget proposal instead of being submitted to the GNAT by the Council of Ministers: This amendment is mainly based on the transition from the parliamentary government model to the presidential government system. Because, in the classical presidential model where the entire authority of the executive power is convened by the president elected by the public, the preparation and approval of the budget is the most basic duty of the representative body. For example, in the United States, where the classical presidential system has been practiced in the best way, Congress, the representative body, has the capacity to refuse, amend or re-prepare its own budget proposal submitted by the executive body. (Inter-Parliamentary Union, 2004, p.44.) 
Biçer N. (2019). Evaluate the existing political oversight role of Turkish parliament over the public finance and in this context analyzed the new Turkish Presidential Government System. Journal of Human Sciences, 16(3), 746-761. doi:10.14687/jhs.v16i3.5666

\section{Parliamentary Budget Process}

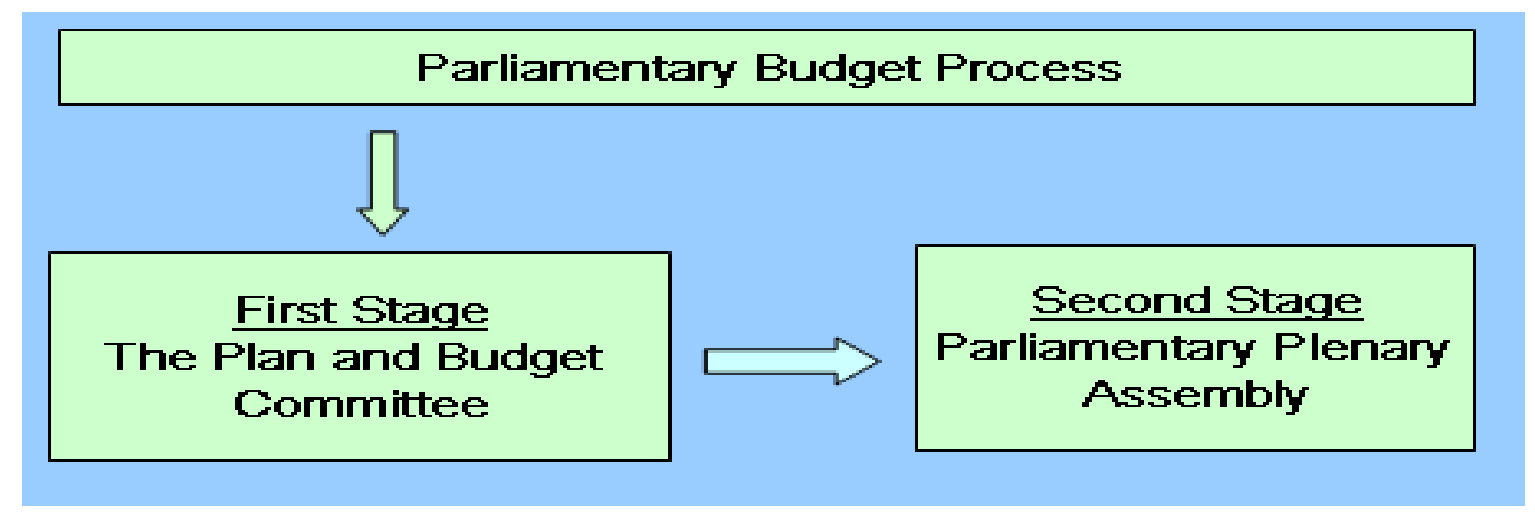

b) The regulation determining the number of members of the Plan and Budget Committee, which is the committee where budget and final account is discussed, has been removed from the Constitution: The sentence determined Plan and Budget Committee consists of 40 members and that at least 25 members belong to the ruling party, has been removed from the Constitution. In the new constitutional government system, in accordance with the traditional presidential system, since the government was not established on the basis of the majority / confidence of the parliament, this numerical exception to ensure the majority of the ruling party / parties was removed from the Constitution. With this Amendment, the distribution of the members of the Plan and Budget Committee to be determined according to the number of members in the GNAT in accordance with the provisions of the Rules of Procedures stipulating the distribution of members of the other committees in the GNAT. 
Biçer N. (2019). Evaluate the existing political oversight role of Turkish parliament over the public finance and in this context analyzed the new Turkish Presidential Government System. Journal of Human Sciences, 16(3), 746-761. doi:10.14687/ihs.v16i3.5666

\section{Budget Cycle: Approval of Parliamentary Budget Process}

\begin{tabular}{|l|l|}
\hline $\begin{array}{l}\text { The President submits the draft Budget Law } \\
\text { to parliament within } 75 \text { days prior to the beginning of the } \\
\text { new fiscal year ( before } 1 \text { January) }\end{array}$ & 17 October \\
\hline $\begin{array}{l}\text { Minister of Treasury and Finance or Vice President } \\
\text { presents the draft Budget Law to the Plan and Budget } \\
\text { Committee. }\end{array}$ & End of October \\
\hline $\begin{array}{l}\text { Draft Budget Law discussed and amended in the Plan } \\
\text { and Budget Committee within } 55 \text { of } 75 \text { days. }\end{array}$ & $\begin{array}{l}\text { Early November- } \\
\text { Early December }\end{array}$ \\
\hline $\begin{array}{l}\text { Draft Budget Law and amendments deliberated and voted } \\
\text { upon in parliamentary plenary session within } 20 \text { of } 75 \\
\text { days. }\end{array}$ & Mid-December \\
\hline $\begin{array}{l}\text { Draft budget law that has been approved by parliament } \\
\text { has to be signed by the President. }\end{array}$ & 31 December \\
\hline
\end{tabular}

c) If the budget "cannot be put in force in time", a provisional budget is adopted, and if this is not possible, then the budget of the previous year is applied, subject to a re-evaluation rate. In order to ensure continuity of the state action, in the event that the budget law is not put into effect at the legal time, GNAT is to issue a provisional budget law. If the GNAT fail to issue the provisional budget law, the President has the right to put into force a provisional budget decree (presidential decree) that determined based on a certain ratio of previous year's initial budget appropriations. This regulation is similar to the enforcement procedure of the provisional budget law in Article 19 of the Law on Public Financial Management and Control No. 5018. However, the main difference from the regulation in Article 19 is that if the GNAT does not accept the provisional budget law, the budget of the previous year will be increased by the re-evaluation rate and will be implemented automatically by President.

This amendment is silent on what happens if the budget proposal is rejected in the Plenary Session of the Parliament. In that case, President might have two way to solve this conflict. First one is that the president could enact a provisional budget decree based on a certain ratio of the reevaluated budget of the previous year, thus bypassing parliament. Secondly the president might reach an agreement with Parliament to enact budget proposal. Because it might essentially increases the budget from the previous year per rate of revaluation, but this might make the executive activities of the president more difficult.

d) Provision for special time and procedures for development plans was removed from amended article 161.

e) The provisions regarding the reading and voting of public administration budgets on section basis was abolished. According to the Law No. 5018, the Parliament deliberates the text of budget draft Law on article basis and the revenue and expenditure schedules on public administration basis, and puts the draft law to a vote on section basis.

f) In the Constitution, the provision for the final account to be submitted to the GNAT within 7 months is changed to 6 months. In fact, since 2006, when the Law No. 5018 came into force, the period of submission to the GNAT has been implemented at the end of the sixth month. (According 
Biçer N. (2019). Evaluate the existing political oversight role of Turkish parliament over the public finance and in this context analyzed the new Turkish Presidential Government System. Journal of Human Sciences, 16(3), 746-761. doi:10.14687/ihs.v16i3.5666

to article 42 of the Law No. 5018) Practically, Final accounts bill were submitted to the Parliament by the Council of Ministers in the previous system.

\section{Budget Cycle State Budget control}

\section{External control by Turkish Courts of Accounts (TCA)}

- Accounting reports by Ministry of Finance

- The General Conformity Statement by TCA

> Draft Final Accounts Law submitted by The President to the Parliament until the end of June of the subsequent fiscal year

- TCA submits the General Conformity Statement to the Parliament within 75 days after the submission of the Draft Final Accounts Law

- Internal control by spending agencies

> The President is not politically responsible for State Budget execution to the Parliament.

When the constitutional amendment outlined above regarding the legislative budget process is examined:

- It can be argued that there is no significant change in the constitutional structure of the legislative budget, except for the regulations relating to submission of draft budget law to parliament with the distribution of members in the budget committee being required by the presidential government system and also the enactment of the provisional budget affair.

- However, in parallel with the transformation of the constitutional structure of government system, a major change has occurred in the process of preparation, discussion and approval of the budget.

- Namely, the budget process, which was open to the influence and direction of the government onetime, which was formed by the ruling party or parties having a majority in Parliament, has left to the parliament directly. That is, GNAT has the monopoly over granting expenditure to the president through the Budget Law and has effective control over the executive body according to the letter of the amended Constitution. That is to mean that, GNAT has had the monopoly over granting expenditure to the president through the budget law and has owned effective oversight over the executive body in this new government system.

\section{Conclusion and Recommendations}

In terms of the effectiveness of the parliamentary process of the budget, other legal and methodological procedures other than the Constitutional amendments are important in the Executive Presidency System. These recommendations are summarized below:

- Establishment of a Separate Public Accounts Committee: Parliamentary oversight of the executive branch is a critical part of the government's system of checks and balances. Legislative bodies conduct much of its oversight through committees, with the support of a number of official 
Biçer N. (2019). Evaluate the existing political oversight role of Turkish parliament over the public finance and in this context analyzed the new Turkish Presidential Government System. Journal of Human Sciences, 16(3), 746-761. doi:10.14687/jhs.v16i3.5666

and offices that investigate, audit, and provide information and analysis on executive branch activities. In the Western democracies, the main emphasis is on establishing an effective and functional check and balance system based on the separation of powers, irrespective of the form of government system. In the effective and functional check and balance system, public account committees undertake a complementary function in the Western democracies. In the context of financial oversight the public accounts committees as is known in the Westminster form of governance is often viewed as the most powerful of all Committees in relation to ex- post scrutiny of public expenditure. Public accounts committees, which are common in the Commonwealth countries, have been established in many countries, especially in Central European countries, after 1990's (TBMM, 2008).

- Participation of Other Sectoral Committees in the Legislative Budget Process: the sectoral expertise of the committees is, up to now, effectively excluded during the parliamentary budgetary process. Making regulations to increase the role of other sectoral committees in the legislative budget process will enable the GNAT to take an active role in the oversight of the budget policies and budget realization results/final accounts. Thus, it will contribute to the establishment of the check and balance mechanism in the political system effectively.

- Establishment of an Independent Research/Budget Analysis Unit in the Parliament: In recent years, to enhance legislative oversight, many parliament have established specialized research services or budget analysis units serving all members of parliament. These budget units in parliament, some in the form of full-blown legislative budget offices, are becoming increasingly common in democratic parliaments. They can aid the legislative, oversight and scrutiny, and, of course, the budgetary functions of parliament.

- Participatory Legislative Budget Process: Structured dialogue and exchange with representatives of interest groups, organised civil society, and experts is a hallmark of modern parliaments and an indispensable part of parliamentary budget process. The key challenge that parliaments and individual parliamentarians face in their exchanges with representatives from a very wide range of organisations and interests is to ensure that open channels of communication such as written statements, presentations, joint seminars and hearings.

Democratic societies were not born out of an abstract idea. They were based on the down-toearth insistence that those who pay the taxes shall have control over how the taxes are used. It therefore follows that democracy as well is about the possibilities that citizens/legislative bodies have of making holders of public office accountable for their decisions and actions. This were conceptualized as the power of purse / budgetary powers which have been conducted by parliament in the representative democracy. For this core fact, Parliaments provide financial authority and powers. They therefore have the right and responsibility to hold governments and its entities accountable for the management and use of the resources entrusted to them. That's why, accountability is one of the most fundamental democratic principles.

In sum, today democracy is a question of confidence, not only to people, but also to institutions. The more confidence citizens have to institutions using public money, the more there is democratic legitimacy. Democratic legitimacy is, however, not only a question of creating democratic institutions. The life of democratic institutions and their way of working must constantly be maintained and developed.

The Executive Presidency System provides new opportunities for the development of democratic institutions through the strengthening of democratic legitimacy for Turkey. The last word is that effective parliamentary participation and oversight in the budget and final account process will contribute to the establishment of confidence and legitimacy in the eyes of citizens, thus, it will 
Biçer N. (2019). Evaluate the existing political oversight role of Turkish parliament over the public finance and in this context analyzed the new Turkish Presidential Government System. Journal of Human Sciences, 16(3), 746-761. doi:10.14687/ihs.v16i3.5666

contribute to strengthening the sense of common interest and, consequently, to a more comprehensive public interest in the Executive Presidency System.

\section{References}

Atiyas, İ. ve Sayın Ş.,(1997), Siyasi Sorumluluk, Yönetsel Sorumluluk ve Bütçe Sistemi: Bir Yeniden Yapılanma Önerisine Doğru, İstanbul: TESEV Yayını, Boyut Matbaacıllk.

Biçer, M., (2017), Türkiye'de Kurala Bağlı Maliye Politikası ve Bütçe Hakkı Temelinde Parlamentonun Etkinliği, Yayımlanmamış Doktora Tezi, Ankara Üniversitesi.

CRT, (2018) Constitution of the Republic of Turkey, https://global.tbmm.gov.tr/docs/constitution_en.pdf.

Çağan, N., (1986), Anayasa Çerçevesinde Kamu Maliyesinin Parlamenter Kontrolü, Anayasa Yargısı, Cilt 2, Anayasa Mahkemesi Yayını, Ankara, pp. 199-224.

Erdoğan M., (2010) Anayasal Demokrasi, 8. Bask1, Siyasal Kitabevi.

Fabrizio S. and Ashoka M., (2006), Can Budget Institutions Counteract Political Indiscipline? International Monetary Fund WP/06/123, 2006.

Harfst, P. and Schnapp, K., (2003) Are Agents Able to Control their Principal's Control Structures? An Empirical Attempt to Measure the Institutional Potential of Parliaments to Control their Executives", ECPR Joint Sessions of Workshops, Workshop 5: Institutional Theory: Issues of Measurement and Change, Edinburgh, March 28 - April 2, http://www.unilueneburg.de/fb2/soz/politik/seiten/team/dokumente/ECPR__ Edinburgh.pdf, (15.05.2010)

Hetzel, R., L., (1997) The Case for a Monetary Rule in a Constitutional Democracy, FRB Richmond Economic Quarterly, Vol. 83, No. 2, Spring, pp. 45-66.

Inter-Parliamentary Union, Parliament,(2004) The Budget and Gender Process: Handbook for Parliamentarians, No. $\quad 6 . \quad$ Available at: http://www.ipu.org/PDF/publications/budget_en.pdf (30.03.2017).

Lane J.E. (1996), Constitutions and Political Theory, First Published, Manchester University Press.

Mouffe C., (2008) Siyasetin Dönüşü, Çev. Fahri Bakırcı ve Ali Çolak, Epos Yayınları.

Musgrave A. R. and Musgrave P. B., (1989) Public Finance in Theory and Practice, 5th edition, McGraw-Hill Book Company.

O'connor J.,(1973) The Fiscal Crisis of the State, St. Martin Press, New York.

OECD/SIGMA (2010), The Administrative Capacity of The Turkish Grand National Assembly, SIGMA Peer Review Report, OECD- SIGMA.

Santiso, C., (2005) "Parliaments and Budgeting: Understanding the politics of the budget", presented at the XVII Regional Seminar on Fiscal Policy of the United Nations Economic Commission for Latin America (ECLAC) in Santiago, Chile, on 24-27 January 2005 and at the Third Annual Meeting Euro-Latino-American Governance for Development Network of the InterAmerican Development Bank (IDB) in Hamburg, Germany, on 12-13 December 2005.

Sartori, G., (1996) Demokrasi Teorisine Geri Dönüş, Çev. Tuncer Karamustafaoğlu ve. Mehmet Turan, Yetkin Yayınevi.

Saybaşı1, K., (1992), İktisat, Siyaset, Devlet ve Türkiye, Bağlam Yayınevi.

Strøm, K., Wolfgang C. M., and Bergman, T., (eds.), (2003) Delegation And Accountability in Parliamentary Democracies Delegation and Accountability in Parliamentary Democracies, Oxford University Press.

Şaylan G., (1998) Demokrasi ve Demokrasi Düşüncesinin Gelişmesi, TODAİE İnsan Hakları Araşturma ve Derleme Merkezi, Ankara.

Şaylan G., (2008) Temsili Liberal Demokrasinin Önlenemez Krizi, 1. Baskı, İmge Kitapevi, Ankara. Şenel Alaeddin, (2017), Siyasal Düşünceler Tarihi, 6. Bask1. 
Biçer N. (2019). Evaluate the existing political oversight role of Turkish parliament over the public finance and in this context analyzed the new Turkish Presidential Government System. Journal of Human Sciences, 16(3), 746-761. doi:10.14687/jhs.v16i3.5666

TBMM (2008) Bütçe Sürecinde Parlamentonun Değişen Rolü, Uluslararası Sempozyum, Bildiri ve Makaleler, Afyonkarahisar 8 - 9 Ekim 2008.

Wolfgang, M., C., Bergman T., and Strøm, K., (2003) Parliamentary Democracy: Promise and Problems'. In Strøm vd., (ed.) Delegation And Accountability in Parliamentary Democracies Delegation and Accountability in Parliamentary Democracies, Oxford University Press, pp. 3-32.

Yıldıran Mustafa, Mahmure Eşünoğlu and Süleyman Bolat (Ed) (2010), Maliye Politikasının Oluşturulmasında Parlamentonun Rolü, Uluslararası Sempozyum Bildiri ve Makaleler, 21-22 Ekim 2010, Sivas.

Yılmaz, H. H. and Biçer, M., Parlamentonun Bütçe Hakkını Etkin Kullanımının Yeni Bütçe Sistemi Çerçevesinde Değerlendirilmesi, 2010, Maliye Dergisi, Ocak-Haziran 2010, Sayı 158, pp. 201 225. 